Електронне наукове фахове видання "Ефективна економіка" включено до переліку наукових фахових видань України з питань економіки

(Категорія «Б», Наказ Міністерства освіти і науки України від 11.07.2019 № 975) www. economy.nayka.com.ua | № 12, 2020|24.12.2020 p.

DOI: $10.32702 / 2307-2105-2020.12 .87$

UDC 658.6:001

L. Syhyda

PhD in Economics, Associate Professor of the Department of Marketing,

Sumy State University, Ukraine

ORCID ID: 0000-0002-0319-8070

\title{
BIBLIOMETRIC AND VISUALIZED ANALYSIS OF FOOD SUPPLY CHAIN RESEARCH IN 2004-2020
}

\author{
Л. О. Сигида, \\ к. е. н., доцент кафедри маркетингу, Сумський державний університет, Украйна
}

\section{БІБЛІОМЕТРИЧНИЙ ТА ВІЗУАЛІЗАЦІЙНИЙ АНАЛІЗ ДОСЛІДЖЕНЬ ІЗ ТЕМАТИКИ ЛАНЦЮГІВ ПОСТАВОК ХАРЧОВИХ ПРОДУКТІВ ЗА 2004-2020 РОКИ}

Nowadays, the importance of the food supply chain concept rises, as the world population increases, and the amount of natural resources decreases. The food supply chain helps to organize the process of food production, distribution, retailing, consumption, and disposal in a more sustainable way, with fewer losses and with larger benefits in compliance with the parameters of product quality and safety. Additionally, making modern food supply chains more sustainable will help to reduce the "domino" effect. However, there is a lack of bibliometric and visualization research in the food supply chain field. The results of the publications analyses in the food supply chain field are presented in the article. The research has been conducted by the application of the bibliometric method and visualization analysis to map the obtained results graphically. To reach the purpose of this study the 1084 published papers were obtained from the Scopus Database. The conducted analysis helped to achieve some valuable insights. Firstly, the total number of publications in the "food supply chain" field is on the rise, with a peak in 2020. Secondly, the theme of the food supply chain becomes global, scientists from different institutions, countries, and continents begin working on it. Moreover, cooperation between countries and institutions is getting closer. Nevertheless, authors from the United Kingdom demonstrate the highest activity. Thirdly, the major current research critical spots in the "food supply chain" field, include sustainability, traceability, planning and optimization, social responsibility, and food waste. Also, the network of relationships between keywords within the research problem forms 7 clusters: food supply, sustainability, food waste, environmental impact, sustainable development, food processing, and inventory control. Furthermore, the research themes in the food supply chain have deepened during 2004-2020, they become more interdisciplinary and diversified. Thus, the findings of this paper and their graphical presentation are relevant and can help scientists to understand the latest achievements and gaps in the "food supply chain" field and offer useful guidance for further researches.

На сьогоднішній день важливість кониепиії ланцюга поставок харчових продуктів зростає, враховуючи збільшенням світового населення та скорочення кількості доступних природних ресурсів. Ланцюг поставок харчових продуктів допомагає організувати прочес виробництва, 
розподілу, споживання та утилізації харчових продуктів із найменшими втратами та 3 найбільшими вигодами при дотриманні параметрів якості та безпечності товарів. Крім того, при побудові сучасних ланџюгів поставок харчових продуктів особливе значення надають їх стійкості, щзо проявляться, у тому числі, зменшенні ефекту «доміно». У статті представлені результати аналізу публікацій у сфері ланцюгів харчових продуктів. Дослідження проводилось із застосуванням бібліометричного методу та візуалізаційного аналізу для наочного відображення результатів. Для досягнення мети иьього дослідження було опращьовано 1084 статті з наукометричної бази даних Scopus. Проведений аналіз допоміг досягти изінних результатів. По-перше, загальна кількість публікаиій у сфері ланцңюгів поставок харчових продуктів має тенденцію до зростання, пік публікачійної активності припадає на 2020 рік. По-друге, тема ланцюгів поставок харчових продуктів стає глобальною, над нею починають прачювати вчені з різних установ, краӥн та континентів. Більще того, співпрачя між краӥнами та установами в рамках дослідження даної тематики стає все тіснішою. Проте автори з Великобританії демонструють найвищу активність. По-третє, до основних поточних критичних напрямків досліджень у сфері ланцюгів поставок харчових продуктів належать стійкість, відстежуваність, планування й оптимізаџія, сочіальна відповідальність та харчові відходи. Крім того, тематика досліджень ланиюгів поставок продуктів харчування поглибилися протягом 20042020 років. Дослідження стають більш міждисциплінарними та диверсифікованими. Таким чином, результати отримані у иій статті та їх графічна інтерпретація є актуальними та можуть допомогти вченим зрозуміти останні досягнення й прогалини в сфері ланцюгів поставок харчових продуктів та надати орієнтири для подальших досліджень.

Keywords: supply chain; food supply chain; bibliometric research; visualization research; cluster.

Ключові слова: ланцюг поставок; ланџюг поставок продуктів харчування; бібліометричне дослідження; візуалізація; кластер.

Introduction and the problem statement. Food supply chain and food supply chain management are modern, well-known and wide-used concepts. Both concepts focus on the optimization of all process of agriculture-based products development and their deliver to end customers. Importance of these concepts arises nowadays. Modern consumers want to know the origin of the food they buy, be sure not only in food's quality, but also in its safety. Due to these, food supply chain is an important issue to analyze.

Analysis of recent research and publications. Food supply chain is a complex concepts and includes such important aspect as traditional supply chain and sustainability.

The problems of sustainability, sustainable development, sustainable business, green entrepreneurship are discussed in the following studies [1-4]. The most significant papers in the fields of supply chain and logistics are [510]. Some aspects of food supply chain management are discussed in the papers [11-13]. But there is still a gap that need to be filled - the question of food supply chain studying in scientific works.

The article aims to investigate the problem of "food supply chain" in-depth based on bibliometric and visualized analysis.

Presentation of the main material. To examine the problem of "food supply chain" in more details we used bibliometric analysis. Bibliometric analysis is a modern powerful tool to analyze big sets of bibliographical data and present obtained results in a proper manner. Bibliometric analysis helps to examine the research problem from different points of view, to highlight the gaps and define directions for further researches.

The structure of current bibliometric study is similar to the structure of other bibliometric studies, for example, [14-19]. The bibliometric analysis in this paper was aimed to collect data in "food supply chain" field. It was conducted according to following steps:

1. Choice of suitable information sources: the reliability of bibliometric analysis largely depends on the rating and transparency of sources for data collection. Accordingly, we have chosen Scopus database as one of the most influential and authoritative.

2. Identification of the search field in the database: to ensure the complexity and integrity of the study we used the search field "title, abstract, keywords".

3. Identification of the search keywords: "food supply chain".

4. Identification of the publication type: "articles" only; conference papers, books and books chapters were excluded. 
5. Choice of the language: English.

6. Choice of subject area: Social Sciences; Economics, Econometrics and Finance; Business, Management and Accounting; Decision Sciences.

7. Determination of research years: from 2004 till 2020 (by 2004 the number of publications per year was less than 10).

8. Manual check: the papers analysis in terms of their relevance.

Thus, for further research 1084 articles were chosen.

The distribution of scientific papers over the years is in Figure 1.

250

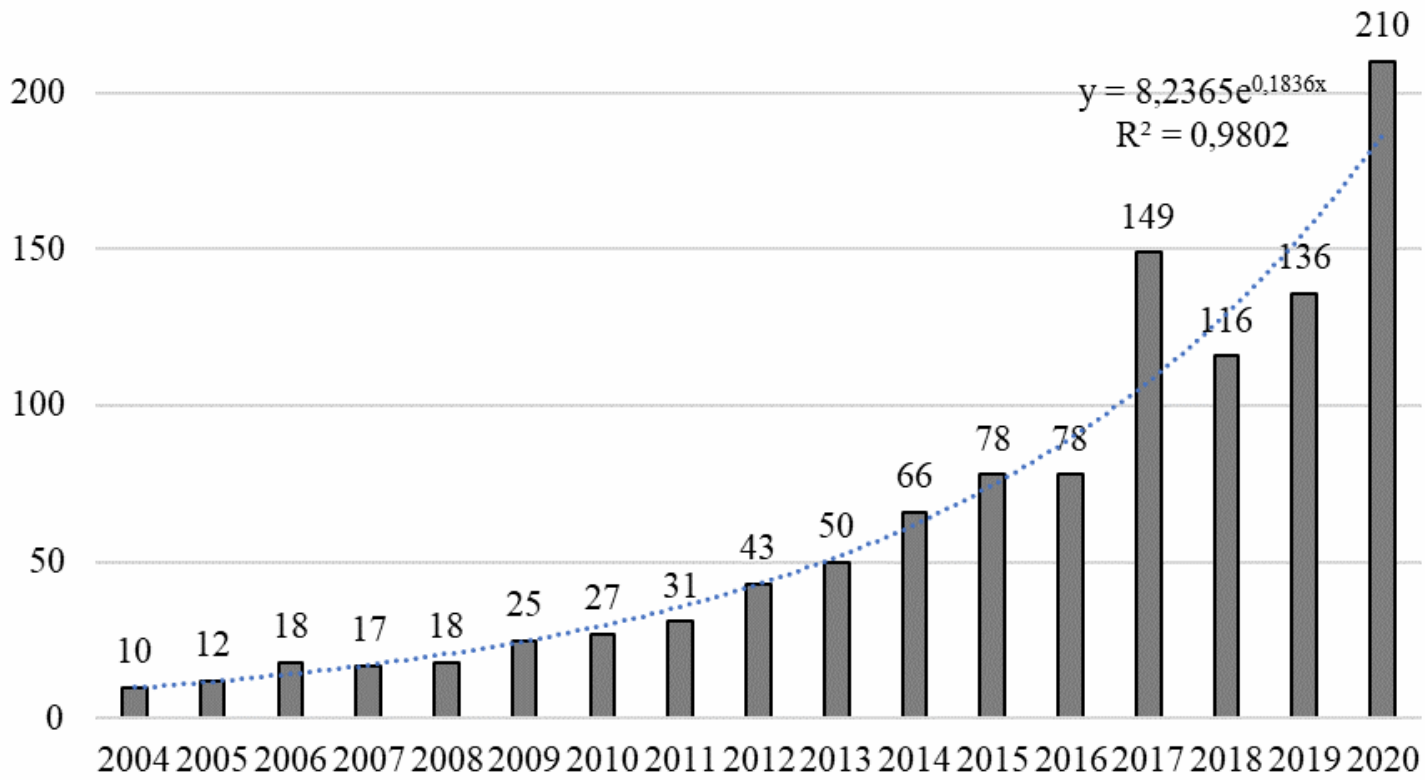

Figure 1. Total number of publications in the "food supply chain" field in 2004-2020 (based on Scopus Database)

Though the first publications in the field of "food supply chain" are dated 70-ties, the growth of publication activity started in 2004. Since then, there has been a steady trend for increasing the number of publications and the trend line proves it. As shown in Figure 1, between 2004-2012, the volume of studies was less than 50 studies per year. From 2013 to 2020, the number of publications has exceeded 50 and reached 210 in 2020 (the peak). Also, more than 63\% of studies were published within the last 5 years (from 2006 to 2020).

Table 1.

The authors with the largest number of published articles in the "food supply chain" research field are in

Table 1. The number of published articles by top 10 contributing authors in "food supply chain" field in 2004-2020 (based on Scopus Database)

\begin{tabular}{cccc}
\hline Author & $\begin{array}{c}\text { Number of published } \\
\text { articles }\end{array}$ & Country of affiliation & $\begin{array}{c}\text { Author's h-index in Scopus } \\
\text { Database }\end{array}$ \\
\hline Manning L. & 10 & United Kingdom & 17 \\
\hline Bourlakis M. & 9 & United Kingdom & 23 \\
\hline Mangla S.K. & 9 & United Kingdom & 28 \\
\hline Maye D. & 9 & United Kingdom & 25 \\
\hline Accorsi R. & 8 & Italy & 19 \\
\hline Ilbery B. & 8 & United Kingdom & 34 \\
\hline Manzini R. & 8 & Italy & 28 \\
\hline Li D. & 7 & United Kingdom & 15 \\
\hline Nakandala D. & 7 & Australia & 8 \\
\hline Sala S. & 7 & Belgium & 34 \\
\hline
\end{tabular}

According to Table 1, all scientists have high h-index in Scopus Database, it proves that their publications are relevant to modern trends and attract attention of world scientific community. The top four contributors of the research area are the following scientist: Manning L., Bourlakis M., Mangla S.K. and Maye D. Country of affiliation of six authors out of ten is the United Kingdom; more two authors are from Italy; one is from Australia and one more is from Belgium. 
Also, we paid attention to the study of geographical coverage of the publication in "food supply chain" research field (Table 2).

Table 2. Countries with the largest number of publications in "food supply chain" field in 2004-2020 (based on Scopus Database)

\begin{tabular}{cc}
\hline Country & Number of published articles \\
\hline United Kingdom & 226 \\
\hline Italy & 152 \\
\hline USA & 144 \\
\hline Netherlands & 93 \\
\hline India & 79 \\
\hline China & 70 \\
\hline Germany & 61 \\
\hline Australia & 52 \\
\hline France & 46 \\
\hline Spain & 45
\end{tabular}

According to Table 2, most articles in "food supply chain" field are published by the scientists from Europe (UK, Italy, the Netherlands, Germany, France and Spain); Asia (China, India), North America (USA) and Australia. Also, scientists from South America and Africa started to work over the problem of food supply chain too. This emphasizes the global relevance and importance of the "food supply chain" problem.

Additionally, using VOSviewer a network that illustrates the main publishing countries in "food supply chain" field was made.

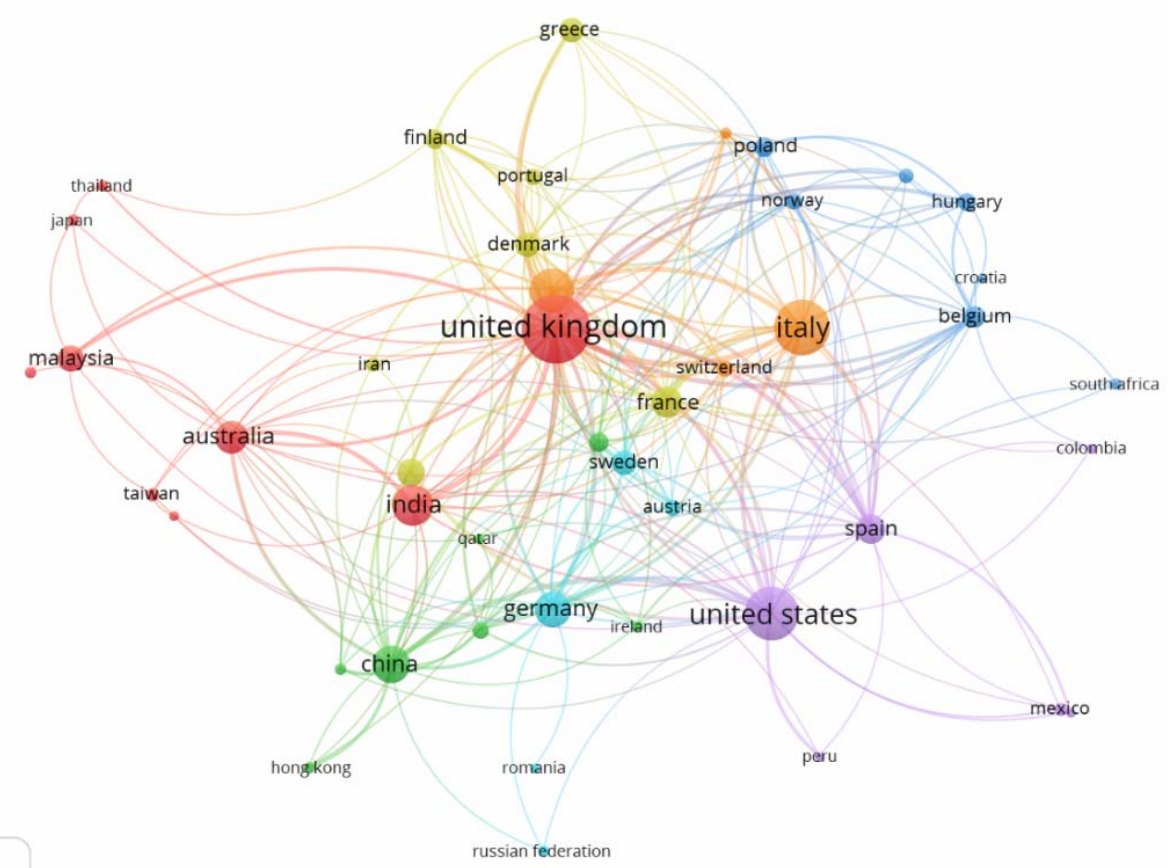

Figure 2. The network of relationships between countries based on Scopus Database, generated using VOSviewer

As a result, seven country clusters were formed. These clusters are formed by the following countries: the United Kingdom (226 documents, 5954 citations), Italy (152 documents, 3384 citations), the USA (144 documents, 3834 citations), China (70 documents, 728 citations), Germany (61 documents, 1362 citations), Denmark (29 documents, 1548 citations), Belgium (24 documents, 551 citations). So, the United Kingdom has a leading position among other countries in publication activity in "food supply chain" field.

Top 10 journals in "food supply chain" field are listed in Table 3. 
Table 3. The number of published articles by top 10 journals in "food supply chain" field in 2004-2020 (based on Scopus Database)

\begin{tabular}{|c|c|c|c|c|c|c|c|c|c|c|c|}
\hline \multirow[b]{2}{*}{ Journal } & \multirow[b]{2}{*}{ Q } & \multirow[b]{2}{*}{ SNIP } & \multirow{2}{*}{$\begin{array}{l}\text { Number of } \\
\text { published } \\
\text { articles }\end{array}$} & \multirow{2}{*}{$\begin{array}{l}\text { Number of } \\
\text { citations }\end{array}$} & \multirow{2}{*}{$\begin{array}{l}\text { Citations } \\
\text { per } 1 \text { publi- } \\
\text { cation }\end{array}$} & \multicolumn{6}{|c|}{ Cited interval } \\
\hline & & & & & & $\geq$ & $\geq$ & $\geq$ & $\geq$ & $\geq$ & $\begin{array}{l}\geq \\
10\end{array}$ \\
\hline $\begin{array}{l}\text { Journal of Cleaner Production } \\
\text { (Netherlands) }\end{array}$ & Q1 & 2.394 & 85 & 2544 & 29,9 & 1 & & 2 & 2 & 5 & 43 \\
\hline $\begin{array}{l}\text { British Food Journal (United } \\
\text { Kingdom) }\end{array}$ & Q1 & 1.086 & 79 & 1415 & 17,9 & & & & & 6 & 42 \\
\hline Sustainability (Switzerland) & Q2 & 1.165 & 71 & 827 & 11,6 & & & & & 4 & 22 \\
\hline $\begin{array}{l}\text { International Journal of } \\
\text { Production Economics } \\
\text { (Netherlands) }\end{array}$ & Q1 & 2.714 & 32 & 2520 & 78,8 & & 3 & & 6 & 12 & 7 \\
\hline Food Policy (United Kingdom & & 2.410 & 28 & & 50,9 & 1 & & & 3 & 3 & 11 \\
\hline $\begin{array}{c}\text { International Journal of } \\
\text { Production Research (United } \\
\text { Kingdom) }\end{array}$ & Q1 & 2.075 & 24 & 823 & 34,3 & & & 1 & 2 & 3 & 5 \\
\hline $\begin{array}{l}\text { International Journal of Supply } \\
\text { Chain Management (United } \\
\text { States) }\end{array}$ & Q2 & 1.176 & 23 & 43 & 1,9 & & & & & & 1 \\
\hline $\begin{array}{l}\text { Resources Conservation and } \\
\text { Recycling (Netherlands) }\end{array}$ & Q1 & 2.584 & 22 & 468 & 21,3 & & & & & 3 & 9 \\
\hline $\begin{array}{l}\text { Production Planning and Control } \\
\text { (United Kingdom) }\end{array}$ & Q1 & 1.809 & 18 & 234 & 13,0 & & & & & 2 & 6 \\
\hline $\begin{array}{l}\text { Production Planning and Control } \\
\text { (United Kingdom) }\end{array}$ & Q1 & 2.158 & 17 & 845 & 49,7 & & & 1 & 2 & 2 & 5 \\
\hline
\end{tabular}

As the Table reveals, the top 10 journals had published 399 papers in "food supply chain" field, accounting more than $1 / 3(36,8 \%)$ of analyzed articles. These journals have high SNIP and almost all belong to Q1, except "Sustainability" and "International Journal of Supply Chain Management" (these two journals belong to Q2). The largest number of articles was published in "Journal of Cleaner Production" (85 articles), it is followed by "British Food Journal" (79 articles) and "Sustainability" (71 articles). In other journals were published 32 and less articles. Nevertheless, the most cited are articles from the following journals - "Journal of Cleaner Production" (2544 citations), "International Journal of Production Economics" (2520 citations) and "British Food Journal" (1415 citations).

On the other hand, the journal with the largest citations per 1 publication is "International Journal of Production Economics". The average number of citations for articles published in this journal is 78,8 , followed by "Food Policy" (50,9), and "Production Planning and Control" (49,7).

Also, this Table gives such indicator as cited interval. It shows the number of papers published in the journal with some citation quantity. In the cited interval $\geq 400$, only two papers had been published: one in the "Journal of Cleaner Production" and one more in "Food Policy". In the cited interval $\geq 300$, three articles were published in the "International Journal of Production Economics". Cited interval $\geq 200$ includes two articles from "Journal of Cleaner Production", one from "International Journal of Production Research" and one more from "Production Planning And Control". According to the citation interval, only two papers were cited more than 400 times in the top 10 journals, 3 papers were cited more than 300 times, 4 papers were cited more than 200 times, 13 papers were cited more than 100 times, and most of the papers were cited in the interval from 10 to 50 times.

Additionally, $50 \%$ of top 10 journals have affiliation of the United Kingdom and more $30 \%$ of the Netherlands.

The 10 most cited publications found in Scopus in "food supply chain" field are in Table 4. All 10 articles were cited more than 200 times. It means that research field is important and burning for world scientific community. 
Table 4. The top 20 most cited papers in "food supply chain" field in 2004-2020 (based on Scopus Database)

\begin{tabular}{|c|c|c|c|c|c|c|}
\hline$\#$ & $\begin{array}{c}\text { Total } \\
\text { citations }\end{array}$ & Article title & Author & $\begin{array}{l}\text { Number of } \\
\text { affiliations/ } \\
\text { universities }\end{array}$ & Countries & $\begin{array}{c}\text { Journal/Year of } \\
\text { publication }\end{array}$ \\
\hline 1 & 498 & $\begin{array}{l}\text { Corporate social } \\
\text { responsibility in the } \\
\text { supply chain: An } \\
\text { application in the food } \\
\text { industry }\end{array}$ & $\begin{array}{l}\text { Maloni M.J., Brown } \\
\text { M.E. }\end{array}$ & 2 & 1 (USA) & $\begin{array}{c}\text { Journal of } \\
\text { Business Ethics, } \\
2006\end{array}$ \\
\hline 2 & 460 & $\begin{array}{l}\text { Application of } \\
\text { planning models in the } \\
\text { agri-food supply chain: } \\
\text { A review }\end{array}$ & $\begin{array}{l}\text { Ahumada O., } \\
\text { Villalobos J.R. }\end{array}$ & 2 & $\begin{array}{l}2 \text { (USA, } \\
\text { Mexico) }\end{array}$ & $\begin{array}{c}\text { European } \\
\text { Journal of } \\
\text { Operational } \\
\text { Research, 2009 }\end{array}$ \\
\hline 3 & 409 & $\begin{array}{l}\text { The food waste } \\
\text { hierarchy as a } \\
\text { framework for the } \\
\text { management of food } \\
\text { surplus and food waste }\end{array}$ & $\begin{array}{c}\text { Papargyropoulou E., } \\
\text { Lozano R.K. } \\
\text { Steinberger J., } \\
\text { Wright N., } \\
\text { Ujang Z.B. }\end{array}$ & 5 & $\begin{array}{l}4 \text { (Switzerland, } \\
\text { United } \\
\text { Kingdom, } \\
\text { Sweden, } \\
\text { Malaysia) }\end{array}$ & $\begin{array}{l}\text { Journal of } \\
\text { Cleaner } \\
\text { Production, } \\
2014\end{array}$ \\
\hline 4 & 402 & $\begin{array}{l}\text { Westernization of } \\
\text { Asian diets and the } \\
\text { transformation of food } \\
\text { systems: Implications } \\
\text { for research and policy }\end{array}$ & Pingali $\mathrm{P}$. & 1 & 1 (USA) & $\begin{array}{l}\text { Food Policy, } \\
2007\end{array}$ \\
\hline 5 & 335 & $\begin{array}{l}\text { Sustainable supply } \\
\text { chain management } \\
\text { practices and dynamic } \\
\text { capabilities in the food } \\
\text { industry: A critical } \\
\text { analysis of the } \\
\text { literature }\end{array}$ & $\begin{array}{l}\text { Beske P., } \\
\text { Land A., } \\
\text { Seuring S. }\end{array}$ & 3 & $\begin{array}{l}2 \text { (USA, } \\
\text { Germany) }\end{array}$ & $\begin{array}{l}\text { International } \\
\text { Journal of } \\
\text { Production } \\
\text { Economics, } \\
2014\end{array}$ \\
\hline 6 & 309 & $\begin{array}{l}\text { Two-echelon multiple- } \\
\text { vehicle location- } \\
\text { routing problem with } \\
\text { time windows for } \\
\text { optimization of } \\
\text { sustainable supply } \\
\text { chain network of } \\
\text { perishable food }\end{array}$ & $\begin{array}{l}\text { Govindan K., } \\
\text { Jafarian A., } \\
\text { Khodaverdi R., } \\
\text { Devika K. }\end{array}$ & 3 & $\begin{array}{l}2 \text { (Denmark, } \\
\text { Iran) }\end{array}$ & $\begin{array}{l}\text { International } \\
\text { Journal of } \\
\text { Production } \\
\text { Economics, } \\
2014\end{array}$ \\
\hline 7 & 304 & $\begin{array}{l}\text { An optimization } \\
\text { approach for managing } \\
\text { fresh food quality } \\
\text { throughout the supply } \\
\text { chain }\end{array}$ & $\begin{array}{c}\text { Rong A., Akkerman } \\
\text { R., Grunow M. }\end{array}$ & 3 & $\begin{array}{l}3 \text { (Germany, } \\
\text { Netherlands, } \\
\text { Finland) }\end{array}$ & $\begin{array}{l}\text { International } \\
\text { Journal of } \\
\text { Production } \\
\text { Economics, } \\
2011\end{array}$ \\
\hline 8 & 283 & $\begin{array}{l}\text { Unraveling the food } \\
\text { supply chain: Strategic } \\
\text { insights from China } \\
\text { and the } 2007 \text { recalls }\end{array}$ & $\begin{array}{c}\text { Roth A.V., } \\
\text { Tsay A.A., Pullman } \\
\text { M.E., Gray J.V. }\end{array}$ & 4 & 1 (USA) & $\begin{array}{l}\text { Journal of } \\
\text { Supply Chain } \\
\text { Management, } \\
2008\end{array}$ \\
\hline 9 & 249 & $\begin{array}{l}\text { RFID-enabled } \\
\text { traceability in the food } \\
\text { supply chain }\end{array}$ & $\begin{array}{l}\text { Kelepouris T., } \\
\text { Pramatari K., } \\
\text { Doukidis G. }\end{array}$ & 2 & $\begin{array}{l}2 \text { (United } \\
\text { Kingdom, } \\
\text { Greece) }\end{array}$ & $\begin{array}{c}\text { Industrial } \\
\text { Management } \\
\text { and Data } \\
\text { Systems, } 2007\end{array}$ \\
\hline 10 & 237 & $\begin{array}{l}\text { Food supply chains } \\
\text { and sustainability: } \\
\text { Evidence from } \\
\text { specialist food } \\
\text { producers in the } \\
\text { Scottish/English } \\
\text { borders }\end{array}$ & $\begin{array}{l}\text { Ilbery B., } \\
\text { Maye D. }\end{array}$ & 1 & $\begin{array}{l}1 \text { (United } \\
\text { Kingdom) }\end{array}$ & $\begin{array}{c}\text { Land Use } \\
\text { Policy, } 2005\end{array}$ \\
\hline
\end{tabular}

Also, there is a scientific discussion that emphasizes the relevance of the research topic. Among the top 10 publications, multi-country cooperation accounted for 6 papers and multi-institution cooperation for 8 papers. 
The top 10 most cited publications can be divided into the following research topics: sustainability (rank 5, 6 and 10), traceability (rank 8,9), planning and optimization (rank 2, 4, 7), social responsibility (rank 1), food waste (rank 3).

Table 5. The most productive institutions in "food supply chain" field in 2004-2020 (based on Scopus Database)

\begin{tabular}{|c|c|c|c|c|c|c|c|c|}
\hline \multirow[b]{2}{*}{ Institution } & \multirow[b]{2}{*}{ Country } & \multirow{2}{*}{$\begin{array}{l}\text { Number of } \\
\text { published } \\
\text { articles }\end{array}$} & \multirow{2}{*}{$\begin{array}{l}\text { Number of } \\
\text { citations }\end{array}$} & \multirow{2}{*}{$\begin{array}{l}\text { Citations per } 1 \\
\text { publi-cation }\end{array}$} & \multicolumn{4}{|c|}{ Cited interval } \\
\hline & & & & & 20 & $\geq$ & $\geq$ & $\begin{array}{l}\geq \\
10\end{array}$ \\
\hline $\begin{array}{c}\text { Wageningen University \& } \\
\text { Research }\end{array}$ & Netherlands & 68 & 2030 & 29,9 & 2 & 2 & 9 & 31 \\
\hline $\begin{array}{l}\text { Alma Mater Studiorum } \\
\text { Università di Bologna }\end{array}$ & Italy & 23 & 478 & 20,8 & & & 3 & 10 \\
\hline Brunel University London & $\begin{array}{l}\text { United } \\
\text { Kingdom }\end{array}$ & 16 & 427 & 26,7 & & 1 & 2 & 5 \\
\hline $\begin{array}{l}\text { Università degli Studi della } \\
\text { Tuscia Viterbo }\end{array}$ & Italy & 14 & 263 & 18,8 & & 1 & & 5 \\
\hline Scotland's Rural College & $\begin{array}{l}\text { United } \\
\text { Kingdom }\end{array}$ & 14 & 379 & 27,1 & & 1 & 2 & 5 \\
\hline Politecnico di Milano & Italy & 12 & 365 & 30,4 & & 1 & 1 & 6 \\
\hline Universität Göttingen & Germany & 12 & 181 & 15,1 & & & & 5 \\
\hline $\begin{array}{l}\text { European Commission } \\
\text { Joint Research Centre }\end{array}$ & Belgium & 12 & 453 & 37,8 & & 1 & 2 & 6 \\
\hline $\begin{array}{c}\text { Cranfield School of } \\
\text { Management }\end{array}$ & $\begin{array}{c}\text { United } \\
\text { Kingdom }\end{array}$ & 12 & 294 & 24,5 & & & 2 & 5 \\
\hline Brunel Business School & $\begin{array}{l}\text { United } \\
\text { Kingdom }\end{array}$ & 12 & 362 & 30,2 & & 1 & 2 & 2 \\
\hline
\end{tabular}

The top 10 institutions have published a total of 195 papers of analyzed, accounting for $18 \%$ of all papers from 2004 to 2020. Wageningen University \& Research (the Netherlands) ranks first with 68 articles. Then there are Alma Mater Studiorum Università di Bologna (Italy), Brunel University London (United Kingdom), Università degli Studi della Tuscia Viterbo (Italy), and Scotland's Rural College (the United Kingdom). Number of published articles within other institutions is equal 12 .

In terms of the frequency of institutional citation, there are one institution whose number of total citations within all papers is more than 2000, three institutions with total citations more than 400, three institutions with total citations more than 300, and three institutions with total citations between 100 and 300. The highest average citations per article is in European Commission Joint Research Centre (37,8), it is followed by Politecnico di Milano (30,4) and Brunel Business School (30,2).

Also, according to Table 5, all institutions are in Europe, four of them are situated in the United Kingdom, more three in Italy.

Just two papers were cited more than 200 times, these papers were published by the scientists from Wageningen University \& Research. Eight articles from seven institutions (except, Alma Mater Studiorum Università di Bologna, Universität Göttingen and Cranfield School of Management) got in cited interval $\geq 100$. Also, in cited interval $\geq 50$ got 23 papers, and in in cited interval $\geq 10$ got 80 articles.

To identify the most frequent keywords relevant to the area and to highlight the existing trends in the research field, the network of relationships between keywords (co-occurrence) was formed using VOSviewer (a reliable and effective tool to visualize the interaction between the main keywords in research).

371 keywords were selected for analysis (minimum number of occurrence of keywords $\geq 5$ ). After the keywords reviewing, repeated words and irrelevant words (such as "Eurasia", "literature review" and others) were excluded from further consideration. At total 118 keywords were analyzed (Figure 3). 


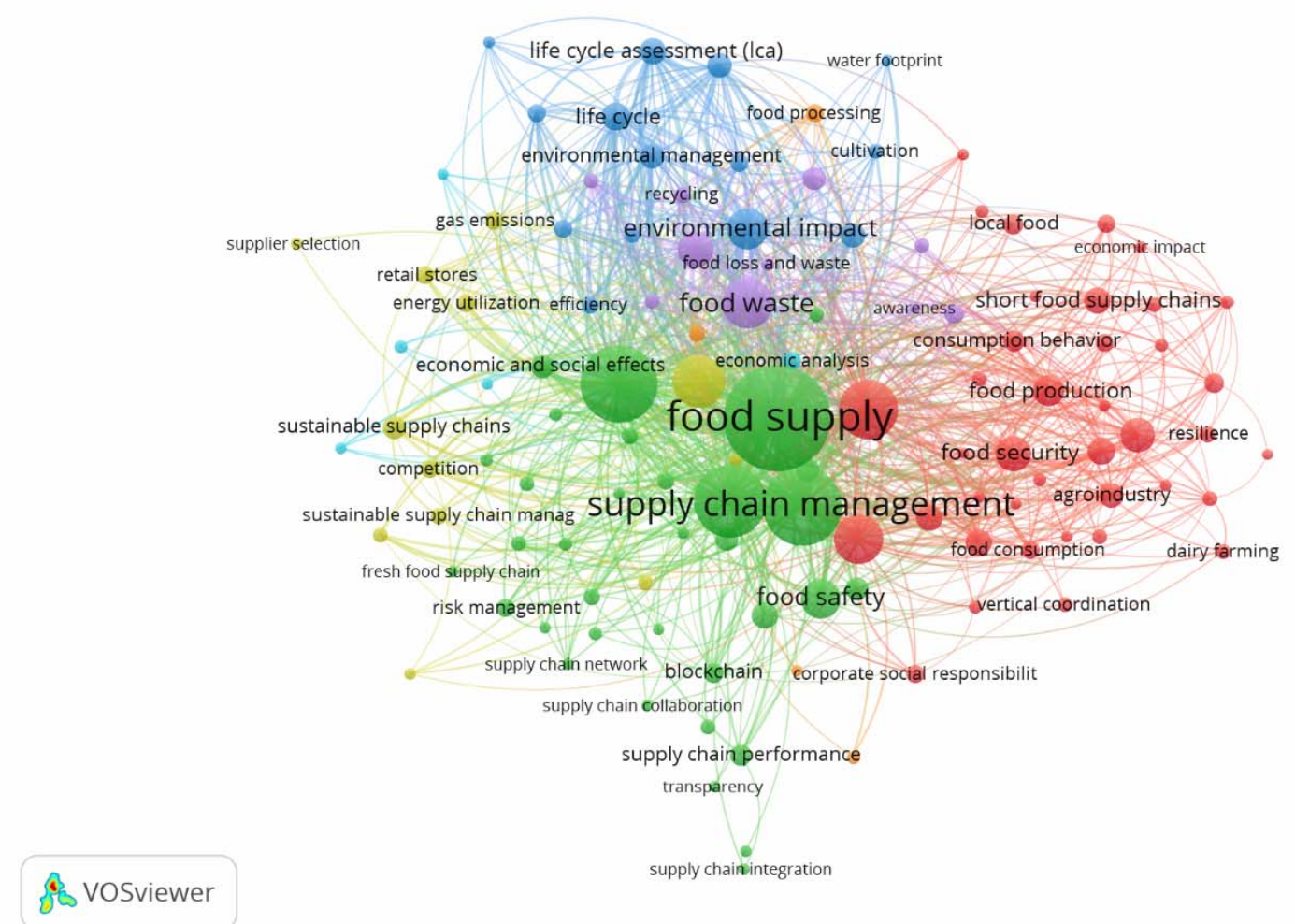

Figure 3. Network of relationships between keywords (based on Scopus Database), generated using VOSviewer

Thus, the generated network visualization between 118 keywords includes 7 clusters. Different clusters are illustrated in different colors. The same color of the nodes and keywords means that they belong to the same cluster. The first (most powerful) cluster (green cluster) forms around the keyword "food supply" (413 occurrences, total link strength - 3329), this cluster includes the following main keywords: supply chain management, food safety, etc.; the second cluster (red cluster) forms around the keyword "sustainability" (128 occurrences, total link strength - 912), includes the following main keywords: food production, food security, etc.; the third cluster (violet cluster) forms around the keyword "food waste" (97 occurrences, total link strength - 834), includes the following main keywords: recycling, food loss, etc.; the fourth cluster (blue cluster) forms around the keyword "environmental impact" (61 occurrences, total link strength - 708), includes the following main keywords: life cycle, environmental management, etc.; the fifth cluster (yellow cluster) forms around the keyword "sustainable development" (100 occurrences, total link strength - 991), includes the following main keywords: energy utilization, sustainable supply chain management, etc.; the sixth cluster (orange cluster) forms around the keyword "food processing" (12 occurrences, total link strength - 54); the seventh cluster (light blue cluster) forms around the keyword "inventory control" (5 occurrences, total link strength $-29)$.

The integral result of the conducted research is the determination of the main scientific aspects in "food supply chain" field and the identification of the scientific gaps in this field. Obtained results not only show current state of publication activity within scientific problem, but also form a basis of further researches.

Conclusions. The article analyzes the concept of food supply chain using the bibliometric method and visualization tool. This paper adopts bibliometric analysis and scientific visualization method to analyze 1084 Scopus papers.

According to achieved results, the rapid growth of publication activity in "food supply chain" field started after 2004. The largest number of publications was reached in 2020 and it was equal 210 papers.

Regarding the countries, the largest number of articles were published by the authors from the United Kingdom, it is followed by Italy and the United States. Also, six authors out of top 10 contributing authors are from the United Kingdom. So, the United Kingdom forms the most powerful network with other countries.

All top journals in the "food supply chain" field have high SNIP and are in Q1 or Q2. Most scientific papers are published in the following journals: "Journal of Cleaner Production", "British Food Journal" and "Sustainability".

The three most cited articles cover five research topics in the "food supply chain" field - sustainability, traceability, planning and optimization, social responsibility, and food waste. Total citation of these articles is equal 3486 .

The top 10 institutions have published a total of 195 papers. All institutions are in Europe. Also, two papers with the affiliation of Wageningen University \& Research were cited more than 200 times.

Additionally, keywords within the research field form 7 clusters which define main components of "food supply chain" concept and improve understanding of further research trends. 
In the further works we will focus on the obtained results to identify gaps in the existing researches and ways of their overlapping to reach more fruitful scientific results.

\section{References.}

1. Vasylieva, T., Lyulyov, O., Bilan, Y., \& Streimikiene, D. (2019), "Sustainable economic development and greenhouse gas emissions: The dynamic impact of renewable energy consumption, GDP, and corruption", Energies, no. 12(17), doi:10.3390/en12173289.

2. Pimonenko T, Chygryn O., Luylov O. (2018), "Green Entrepreneurship as an Integral Part of the National Economy Convergence", National Security \& Innovation Activities: Methodology, Policy and Practice: monograph : Drukarnia i Studio Graficzne Omnidium, pp. 358-365.

3. Liulov O., Pimonenko T, Stoyanets N., Letunovska N. (2019), "Sustainable Development of Agricultural Sector: Democratic Profile Impact Among Developing Countries", Research in World Economy, vol. 10, no. 4, pp. 97 105, https://doi.org/10.5430/rwe.v10n4p97

4. Bilan Y., Pimonenko T., Starchenko L. (2020), "Sustainable business models for innovation and success: Bibliometric analysis", in E3S Web of Conferences, 159, 04037.

5. Kazemi N., Modak N., Govindan K. (2019), "A review of reverse logistics and closed loop supply chain management studies published in IJPR: a bibliometric and content analysis", International Journal of Production Research, no. 57(15-16), pp. 4937-4960.

6. Fahimnia B., Sarkis J., Davarzani H.. (2015), "Green supply chain management: A review and bibliometric analysis", Int. J. Production Economics, no. 162, pp. 101-114.

7. Haidabrus N.V., Bilovodska O.A., Saher L.Y. (2014), "Logistic service in the innovative production distribution channels as its optimal structure factor", Actual Problems of Economics, no. 11, pp. 147-153.

8. Bilovodska O., Syhyda L., Saher L. (2018). "Supply chain management: world's companies experience", MIND Journal, no. 5, pp. 1-17.

9. Taraniuk L., Wang J., Qiu H., Petrushenko Y., Taraniuk K. (2019), "International aspects of assessing the logistic potential of the main countries of agricultural production", Problems and Perspectives in Management, no. 17(3), pp. 31-44.

10. Olefirenko O. (2015), "Theoretical and methodic grounds to identify potential sales markets of innovative production for Ukrainian machine building enterprises", Problems and Perspectives in Management, no. 13(4), pp. 6369.

11. Noomhorm A., Ahmad I. (2008), "Food Supply Chain Management and Food Safety: South \& East-Asia Scenario", Agricultural Information Research, no. 4(4), pp. 131-136, DOI: 10.3173/air.17.131

12. Carbone A. (2017), "Food supply chains: coordination governance and other shaping forces", Agricultural and Food Economics, no. 5(1), DOI: 10.1186/s40100-017-0071-3

13. Kumar A., Kushwaha G.S. (2014), "Food Supply chain Management sustainability: A Review”, TIJ's Research Journal of Science \& IT Management, no. 3 (10), pp. 30-42.

14. Albort-Morant G., Henseler J., Leal-Millán A., Cepeda-Carrión G. (2017), "Mapping the Field: A Bibliometric Analysis of Green Innovation”, Sustainability, no. 9(6), 1011.

15. Bilan Y., Pimonenko T., Starchenko L. (2020), "Sustainable business models for innovation and success: Bibliometric analysis", in E3S Web of Conferences, 159, 04037.

16. Shvindina H. (2019), "Coopetition as an Emerging Trend in Research: Perspectives for Safety \& Security", Safety, no. 5(3).

17. Capobianco-Uriarte M.D.L.M., Casado-Belmonte M.D.P., Marín-Carrillo G., Terán-Yépez E. (2019), “A Bibliometric Analysis of International Competitiveness (1983-2017)”, Sustainability, no. 11, 1877.

18. Hallinger P., Kovačević J. (2019), "A Bibliometric Review of Research on Educational Administration: Science Mapping the Literature, 1960 to 2018", Review of Educational Research, no. 89(3), pp. 335-369.

19. Cheng Wang, Tao Lv and Xu Deng. (2020), "Bibliometric and visualized analysis of food supply chain research 2004-2020", Systematic Review, vol. 5, article 551147, pp. 1-21, doi: 10.3389/frma.2020.551147

\section{Бібліографічний список.}

1. Vasylieva, T. Lyulyov, O. Bilan, Y. and Streimikiene, D. (2019), "Sustainable economic development and greenhouse gas emissions: The dynamic impact of renewable energy consumption, GDP, and corruption", Energies, Vol. 12(17). doi:10.3390/en12173289.

2. Pimonenko, T. Chygryn, O. and Luylov, O. (2018), "Green Entrepreneurship as an Integral Part of the National Economy Convergence", National Security \& Innovation Activities: Methodology, Policy and Practic, Drukarnia i Studio Graficzne Omnidium, pp. 358-365.

3. Liulov, O. Pimonenko, T. Stoyanets, N. and Letunovska, N. (2019), "Sustainable Development of Agricultural Sector: Democratic Profile Impact Among Developing Countries", Research in World Economy, Vol. 10, No 4, pp. 97-105. https://doi.org/10.5430/rwe.v10n4p97

4. Bilan, Y. Pimonenko, T. and Starchenko, L. (2020), "Sustainable business models for innovation and success: Bibliometric analysis", E3S Web of Conferences, Vol. 159, 04037. 
5. Kazemi, N. Modak, N. and Govindan, K. (2019), “A review of reverse logistics and closed loop supply chain management studies published in IJPR: a bibliometric and content analysis", International Journal of Production Research, Vol. 57(15-16), pp. 4937-4960.

6. Fahimnia, B. Sarkis, J. and Davarzani, H. (2015), "Green supply chain management: A review and bibliometric analysis", Int. J. Production Economics, Vol. 162, pp. 101-114.

7. Haidabrus, N.V. Bilovodska, O.A. and Saher, L.Y. (2014), "Logistic service in the innovative production distribution channels as its optimal structure factor", Actual Problems of Economics, Vol. 11, pp. 147-153.

8. Bilovodska, O. Syhyda, L. and Saher, L. (2018), "Supply chain management: world's companies experience", MIND Journal, Vol. 5, pp. 1-17.

9. Taraniuk, L. Wang, J. Qiu, H. Petrushenko, Y. and Taraniuk, K. (2019), "International aspects of assessing the logistic potential of the main countries of agricultural production", Problems and Perspectives in Management, Vol. 17(3), pp. 31-44.

10. Olefirenko, O. (2015), "Theoretical and methodic grounds to identify potential sales markets of innovative production for Ukrainian machine building enterprises", Problems and Perspectives in Management, Vol. 13(4), pp. 6369.

11. Noomhorm, A. and Ahmad, I. (2008), "Food Supply Chain Management and Food Safety: South \& EastAsia Scenario", Agricultural Information Research, Vol. 4(4), pp.131-136. DOI: 10.3173/air.17.131

12. Carbone, A. (2017), "Food supply chains: coordination governance and other shaping forces", Agricultural and Food Economics, Vol. 5(1). DOI: 10.1186/s40100-017-0071-3

13. Kumar, A. and Kushwaha G.S. (2014), "Food Supply chain Management sustainability: A Review”, TIJ'S Research Journal of Science \& IT Management, Vol. 3 (10), pp. 30-42.

14. Albort-Morant, G. Henseler, J. Leal-Millán, A. and Cepeda-Carrión, G. (2017), "Mapping the Field: A Bibliometric Analysis of Green Innovation”, Sustainability, Vol. 9(6), pp. 10-11.

15. Bilan, Y. Pimonenko, T. and Starchenko, L. (2020), "Sustainable business models for innovation and success: Bibliometric analysis", E3S Web of Conferences, Vol. 159, 04037.

16. Shvindina, H. (2019), "Coopetition as an Emerging Trend in Research: Perspectives for Safety \& Security", Safety, Vol. 5(3).

17. Capobianco-Uriarte, M.D.L.M. Casado-Belmonte, M.D.P. Marín-Carrillo, G. and Terán-Yépez, E. (2019), “A Bibliometric Analysis of International Competitiveness (1983-2017)”, Sustainability, vol. 11. 1877.

18. Hallinger, P. and Kovačević, J. (2019), "A Bibliometric Review of Research on Educational Administration: Science Mapping the Literature, 1960 to 2018”, Review of Educational Research, Vol. 89(3), pp. 335369.

19. Wang, Cheng Lv, Tao and Deng, Xu (2020), "Bibliometric and visualized analysis of food supply chain research 2004-2020”, SYSTEMATIC REVIEW, Vol. 5, Article 551147, pp. 1-21. doi: 10.3389/frma.2020.551147

Стаття надійшла до редакиії 03.12.2020 p. 